\title{
RADIOCARBON AGE ANOMALIES IN PRE- AND POST-BOMB LAND SNAILS FROM THE COASTAL MEDITERRANEAN BASIN
}

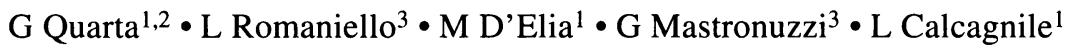

\begin{abstract}
The shell carbonate of pre- and post-bomb samples of 2 species of terrestrial gastropods (Theba pisana and Cernuella virgata) sampled along the coast of Apulia, southern Italy, were dated using accelerator mass spectrometry and carbon stable isotopes were analyzed. The analyses show, for both species, significant anomalies in the radiocarbon age due to the possible presence of a ${ }^{14} \mathrm{C}$-depleted source of carbon in the formation of the shell aragonite. The magnitude of the age anomaly was quantified in the studied area to $\sim 1000{ }^{14} \mathrm{C} \mathrm{yr}$.
\end{abstract}

\section{INTRODUCTION}

Fossil shells of terrestrial gastropods (land snails) are a quite common, usually well-preserved material within geological and archaeological quaternary sequences. The shells can be regarded as important paleoecological and paleoenvironmental indicators (Zhou at al. 1999; Goodfriend and Ellis 2000; Goodfriend et al. 2002). We report on the use of the carbon isotopic composition of terrestrial gastropods shells to provide quantitative information about the type of vegetation consumed by the organisms, the relative distribution of $\mathrm{C}_{3}$ and $\mathrm{C}_{4}$ plants (Goodfriend and Magaritz 1987; Goodfriend 1992), and the reconstructions of temperature variations (Stott 2002). In this context, the possibility of being able to radiocarbon date these samples has some significance. Furthermore, terrestrial gastropods shells are in some cases the only materials available for ${ }^{14} \mathrm{C}$ dating, e.g. in geological studies to reconstruct the sequence of the eolian morphogenetic phase in coastal areas (Mastronuzzi and Sansò 2002), and to reconstruct sea-level changes (Jedoui et al. 1998). Nevertheless, several studies have demonstrated that terrestrial gastropods can give anomalously old ${ }^{14} \mathrm{C}$ ages. Rubin et al. (1963) suggested that anomalous ${ }^{14} \mathrm{C}$ ages could be related to the contribution of a ${ }^{14} \mathrm{C}$-depleted source of carbon in the diet of these animals, probably calcium carbonate derived from limestone. This was later confirmed by others (Tamers 1970; Evin et al. 1980).

Goodfriend and Hood (1983) described a model for the formation of shell aragonite in terrestrial gastropods, suggesting 3 possible sources of carbon: plants, atmospheric $\mathrm{CO}_{2}$, and ${ }^{14} \mathrm{C}$-depleted limestone. On the basis of this model, a set of equations was derived allowing the quantification of the relative contribution of the 3 carbon sources once the carbon isotopic composition (both ${ }^{13} \mathrm{C} /{ }^{12} \mathrm{C}$ and ${ }^{14} \mathrm{C} /{ }^{12} \mathrm{C}$ ) of the shell aragonite is known. A proportion of shell carbonate derived from limestone ranging between 1 and 33\% was estimated in this way in pre-bomb Jamaican land snails (Goodfriend and Hood 1983).

The hypothesis of a ${ }^{14} \mathrm{C}$-depleted source of carbon in the formation of the gastropods' shells has since been confirmed by several studies performed on fossil and modern-collected shells of different species from different geological locations. Results on coastal/non-coastal, arid/semi-arid, and limestone/non-limestone areas have been extensively reported showing that the magnitude of the age anomaly can significantly vary among species and in different geological and environmental settings (Goodfriend and Stipp 1983; Yates 1986; Goodfriend 1987; Goodfriend et al. 1999).

\footnotetext{
'Department of Engineering of Innovation and CEDAD, University of Lecce, Italy.

${ }^{2}$ Corresponding author. Email: gianluca.quarta@unile.it.

${ }^{3}$ Department of Geology and Geophysics, University of Bari, Italy.
} 
More recently, however, Stott (2002), in a labeled feeding experiment, found no appreciable difference in the carbon stable isotopic composition of the shell carbonate of Helix aspersa between animals fed $\mathrm{CaCO}_{3}$ in their diets and those that were not fed with $\mathrm{CaCO}_{3}$. Based on these results, Stott (2002) concluded that ingested $\mathrm{CaCO}_{3}$ does not have any systematic influence on the isotopic composition of shell carbonate; only metabolic $\mathrm{CO}_{2}$ is involved as a source of carbon.

The present study attempts to address the issue of the contribution of ${ }^{14} \mathrm{C}$-depleted sources of carbon in the formation of the shell carbonate of Theba pisana and Cernuella virgata gastropods by measuring the carbon isotopic composition (both ${ }^{13} \mathrm{C} /{ }^{12} \mathrm{C}$ and ${ }^{14} \mathrm{C} /{ }^{12} \mathrm{C}$ ) on both pre-bomb samples and animals sampled alive along the coasts of the Apulian region, central Mediterranean Basin, in different geological settings. The aim of the study was to test Goodfriend's (1987) hypothesis on samples taken along the central Mediterranean coasts and to give an estimation of the magnitude of the effect to be used for correction purposes for a geographical area where no data are thus far available.

\section{METHODS}

Two of the most diverse species of terrestrial gastropods along the southern Italian coast have been chosen for this study: Theba pisana (Müller, 1774) and Cernuella virgata (Da Costa, 1778) (Figure 1a,b). T. pisana is an helicid land snail that is abundant on the coastal areas of the Mediterranean. T. pisana has a white-yellow shell, often pinkish, with brown stripes with a diameter of 15$23 \mathrm{~mm}$ for adult individuals. During warm periods, $T$. pisana lives in an aestivation state in humid areas such as vegetated dunes on plants like Ammophila or other graminaceous (Giusti and Castagnolo 1982) species. Like all helicid snails, T. pisana is a cross-fertilizing hermaphrodite. Cernuella virgata has a yellow shell with brown stripes with a diameter of 9-22 $\mathrm{mm}$. It lives on calcareous grounds and in particular on inland dunes (Giusti and Castagnolo 1982).
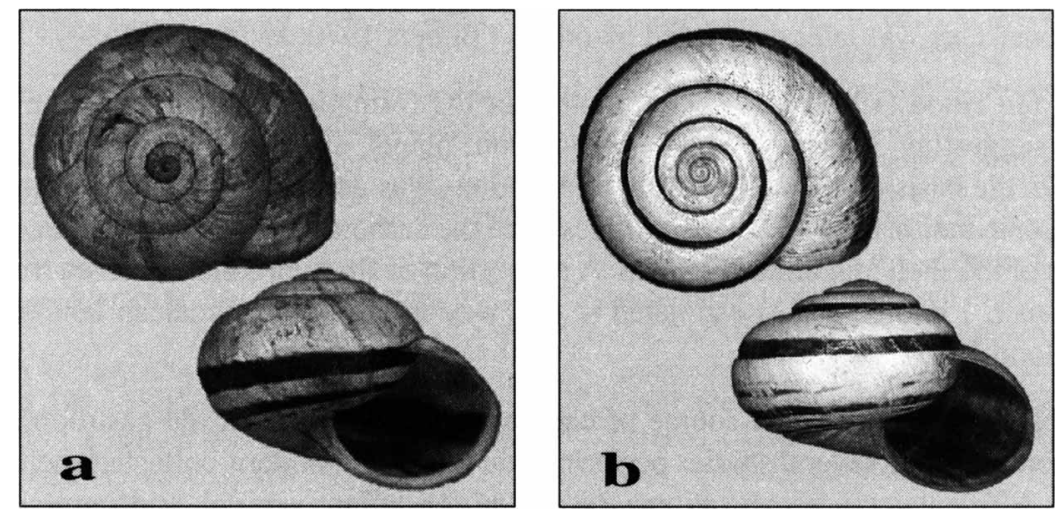

Figure 1 The studied species of terrestrial gastropods: a) Theba pisana (Müller, 1774) and b) Cernuella virgata (Da Costa, 1778).

An important feature of these 2 species is related to their life cycle. Although both species can exhibit an annual or a biennial life cycle depending on climatic factors and food and calcium availability during the growing season (Cowie 1984), in coastal Mediterranean areas an annual life cycle can be expected (Sacchi 1990). The annual life cycle of these species makes significantly easier the interpretation of the ${ }^{14} \mathrm{C}$ results, especially for the post-bomb samples, since the ${ }^{14} \mathrm{C}$ concentration in their shells should reflect only the atmospheric concentration in the year of growth, which can be easily estimated by measuring contemporary, short-lived terrestrial samples. 
Three kinds of samples were selected for this study: modern animals sampled alive in 2004, prebomb samples taken from a museum collection, and subfossil samples recovered from a coastal sedimentary sequence.

The analysis of post-bomb samples collected alive has the significant advantage that the exact sampling location and date are known, together with precise geological and environmental information, enabling an estimation of the expected isotopic composition of the shells. On the other hand, the yearly variation of the ${ }^{14} \mathrm{C}$ concentration in the post-bomb atmosphere as well as the possible presence of local effects (i.e. those related to the presence of industrial sources) can result in some difficulties and uncertainties in the estimation of the age anomaly. For this reason, the data on post-bomb samples were integrated with the data obtained on pre-bomb samples collected in AD 1850 and from geological sedimentary sequences.

\section{Post-Bomb Samples}

Modern land snails were sampled alive in 2004 along the Adriatic and Ionian coasts of the Apulian Peninsula in the central Mediterranean Basin. The geological features of the sampling areas have been described in detail elsewhere (Romaniello et al. 2007): the Apulian coasts are represented by small coastal plains and gentle, rocky coasts dissected by pocket beaches bordered by eolian dune belts (Caldara et al. 1998; Mastronuzzi and Sansò 2002; Mastronuzzi and Romaniello, forthcoming). Previous geomorphologic surveys led to the identification of 3 phases of eolian units, chronologically attributed by means of archaeological studies as well as ${ }^{14} \mathrm{C}$ and optically stimulated luminescence (OSL) determinations to the middle Holocene, the Greek-Roman period, and the Middle Ages (Mastronuzzi and Sansò 2002). Climatologically, the investigated area is in the center of the Mediterranean Sea and is characterized by the classic Mediterranean climate. The 4 sampling areas are indicated in Figure 2: Torre San Leonardo Bay, Fortore River, Cisaniello, and Metaponto coastal plains.

These 4 areas were chosen because they exhibit different lithological features: the present-day sands are mainly terrigenous and siliciclastic in Fortore and Metaponto, but are bioclastic in the remaining sites. Gastropods were sampled on the top of the dune ridge at different distances from the shoreline, on basements of different age.

\section{Pre-Bomb Samples}

A pre-bomb Theba pisana sample, collected in $\mathrm{AD}$ 1850, was obtained from the private collection of Prof Giusti, previously belonging to the Accademia dei Fisiocratici in Siena, Italy. Other prebomb samples were collected from an erosive surface cutting a sedimentary sequence at the Il Pilone locality, close to Torre San Leonardo Bay, where they were associated with both terrestrial and marine samples. The Pilone beach site is characterized by the presence of a continuous vegetated dune ridge. The ridge is up to $9 \mathrm{~m}$ high and in the southernmost part of the beach is cut by an erosive surface placed about $150 \mathrm{~cm}$ above sea level. This surface is covered by gray bioclastic sands marked at the base by a mixed assemblage of terrestrial and marine remains, such as cuttlebones and marine bivalves, terrestrial gastropods subfossil shells, pumices, and charcoals. The entire level is about $30 \mathrm{~cm}$ thick and is enclosed by a $1-\mathrm{mm}$ layer of oxide grains.

\section{Sample Processing and AMS Measurement}

The shell carbonate was extracted from both the modern and subfossil samples by using a standard processing procedure. This consisted of a preliminary mechanical cleaning under optical microscopy for the removal of macro contaminants, followed by cleaning with $30 \% \mathrm{H}_{2} \mathrm{O}_{2}$ in an ultrasonic 


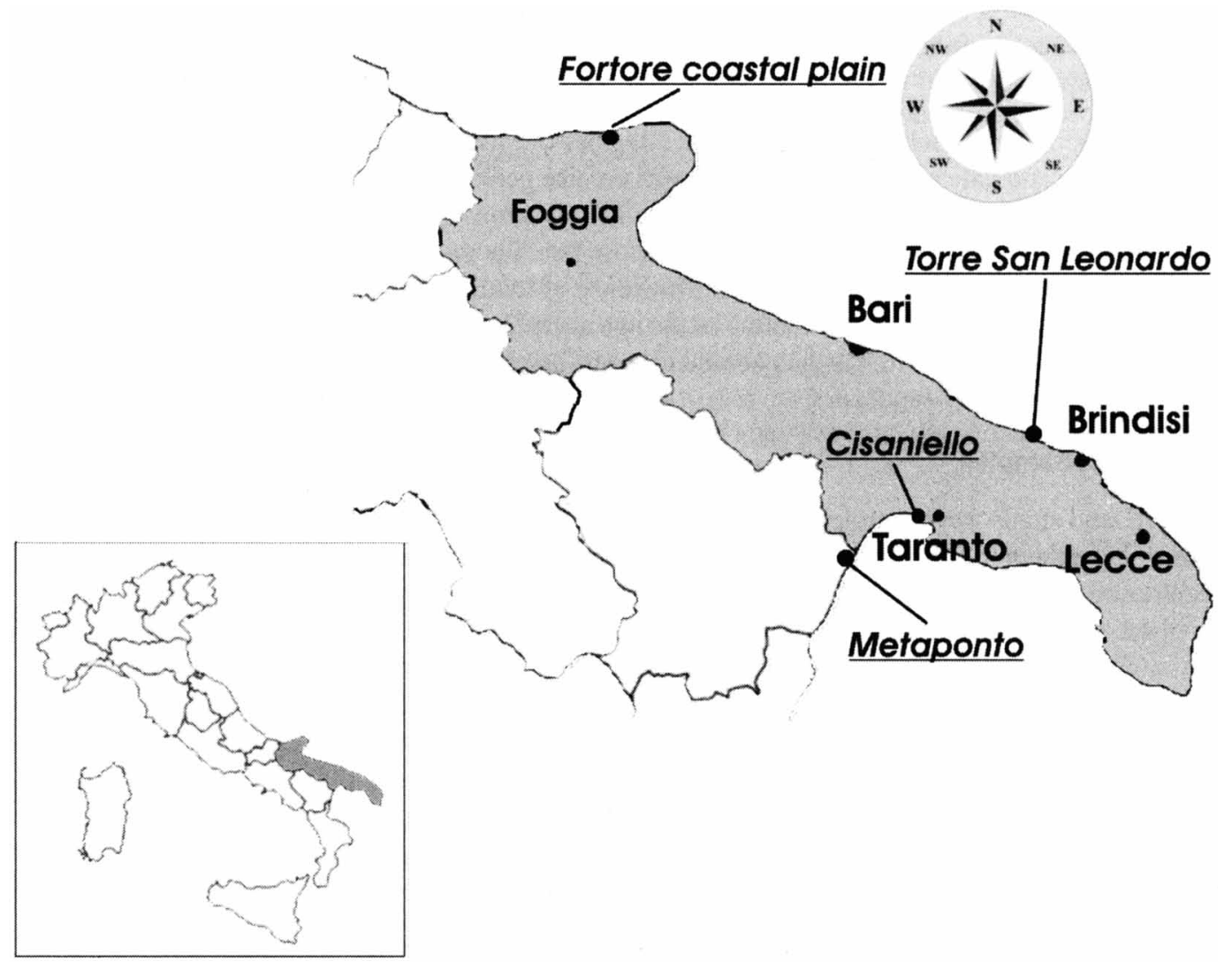

Figure 2 Sampling sites for the modern, live-collected samples

bath to remove the external layer of the shell. Some 8-10 $\mathrm{mg}$ of the precleaned samples, dried in an oven at $60^{\circ} \mathrm{C}$ for $8 \mathrm{hr}$, were then treated with ultra high-purity $15 \% \mathrm{H}_{2} \mathrm{O}_{2}$ and then converted to $\mathrm{CO}_{2}$ in quartz ampoules by $\mathrm{H}_{3} \mathrm{PO}_{4}$ hydrolysis. The cryogenically purified $\mathrm{CO}_{2}$ was finally reduced to graphite at $600{ }^{\circ} \mathrm{C}$ by using $\mathrm{H}_{2}$ as a reducing medium and iron powder as the catalyst (D'Elia et al. 2004). The graphite obtained was pressed into target holders at the accelerator mass spectrometer at CEDAD, University of Lecce, for measuring the carbon isotopic ratios (Calcagnile et al. 2004).

The International Atomic Energy Agency (IAEA) C6 sucrose, with a nominal ${ }^{14} \mathrm{C}$ concentration of $150.61 \mathrm{pMC}$, and $\mathrm{C} 1$ Carrara marble (carbonate standard), with a nominal ${ }^{14} \mathrm{C}$ content of $0 \mathrm{pMC}$, were used as standards for the normalization and estimation of the measurement background, respectively (Calcagnile et al. 2005).

\section{RESULTS}

The ${ }^{14} \mathrm{C}$ concentrations and the $\delta^{13} \mathrm{C}$ values (relative to PDB) obtained for the live-collected samples are shown in Figure 3. The 2004 atmospheric ${ }^{14} \mathrm{C}$ concentration, as measured in the same area by analyzing $\mathrm{C}_{3}$ Agropyron repens plants, is reported for comparison. $\delta^{13} \mathrm{C}$ values range from $-18.0 \pm$ $0.3 \%$ o to $-8.4 \pm 0.7 \%$ with an average value $(n=9)$, calculated from the data scattering $\left(\delta^{13} C_{\text {mean }}\right)$, of $-12.6 \pm 0.9 \%$. Although the carbon stable isotopes data are consistent with values observed by Stott (2202) for the shell carbonate of Helix aspersa land snails fed with $\mathrm{C}_{3}$ plants, the ${ }^{14} \mathrm{C}$ data 
clearly exhibit, for both Theba pisana and Cernuella virgata samples, a significant anomaly, with all the samples having a ${ }^{14} \mathrm{C}$ concentration below the atmospheric value. The ${ }^{14} \mathrm{C}$ data suggest, therefore, a contribution to the diet of these organisms of a carbon source with a characteristic ${ }^{14} \mathrm{C}$ isotopic signal different from the atmospheric value. This is in agreement with Goodfriend and Stipp's (1983) suggestion of ${ }^{14} \mathrm{C}$-depleted calcium carbonate being derived from limestone of geological origin.

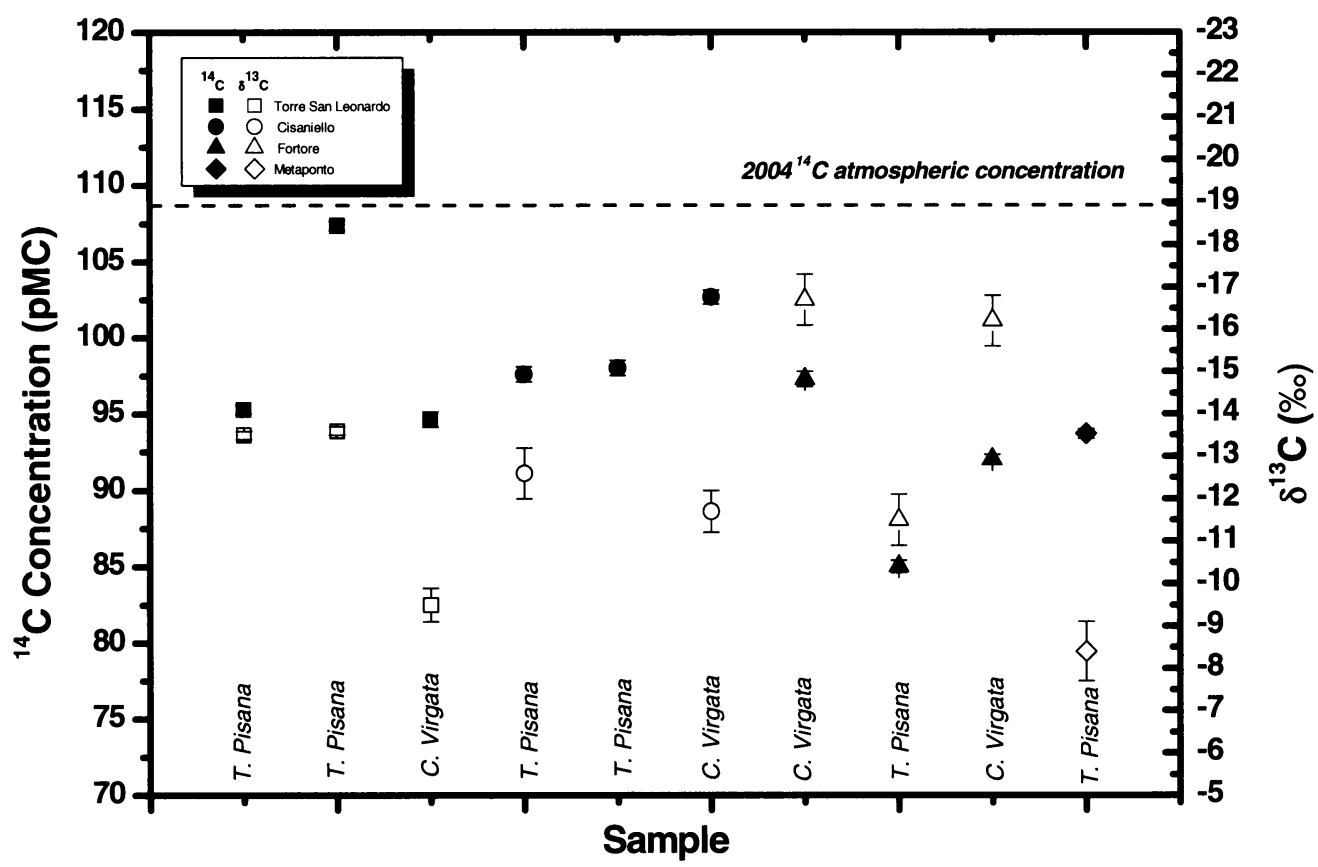

Figure 3 Results of the ${ }^{14} \mathrm{C}$ and stable isotopes measurements for the live-sampled terrestrial gastropods. The filled and empty symbols refer to ${ }^{14} \mathrm{C}$ and stable isotopes measurements, respectively.

The ${ }^{14} \mathrm{C}$ and stable isotopes data were then used-by assuming 3 possible sources involved in the formation of the shell carbonate (i.e. air, plants, and limestone) and following the model developed by Goodfriend and Hood (1983) and the modifications by Pigati (2002) - to calculate the proportion of air-, plant-, and limestone-derived carbon in the gastropods' diet. In particular, the following hypotheses about the isotopic composition of the 3 sources have been assumed: i) the limestone carbonate is completely depleted in ${ }^{14} \mathrm{C}\left({ }^{14} \mathrm{C}\right.$ age $\left.>50 \mathrm{kyr}\right)$ and has a $\delta^{13} \mathrm{C}$ value of $\sim 0$; ii) the plants have a $\delta^{13} \mathrm{C}$ value of $-25 \%$, which is typical for plants with a $\mathrm{C}_{3}$ photosynthetic pathway; iii) air has a $\delta^{13} \mathrm{C}$ value of $+1 \%$, where this value takes into account the actual $\delta^{13} \mathrm{C}$ value for air $(-7 \%$ ) and the fractionation effect due to the dissolution in water $\left(+8 \%\right.$ ). The ${ }^{14} \mathrm{C}$ concentration of $108.70 \pm 0.47$ pMC, measured for Agropyron repens with a $\mathrm{C}_{3}$ photosynthetic pathway, collected in the same area at the same time, was used as reference for the calculation of the age anomaly and to express the ${ }^{14} \mathrm{C}$ content in air and plants (Quarta et al. 2005).

The age anomaly, estimated by using Goodfriend and Hood's (1983) model for carbon uptake, is given in Figure 4 for the modern samples. The results show that all of the live-collected samples gave ${ }^{14} \mathrm{C}$ ages older than expected, with an age anomaly ranging from $281 \pm 20$ for a sample collected in Torre San Leonardo to $2141 \pm 40 \mathrm{yr}$ for a sample collected at the Fortore coastal plain. The 
results do not show any immediate correlation between the sampling location and the measured age anomaly. In particular, no correlation was found with the distance of the sampling site from the shoreline and with the different lithological features of the sampling sites.

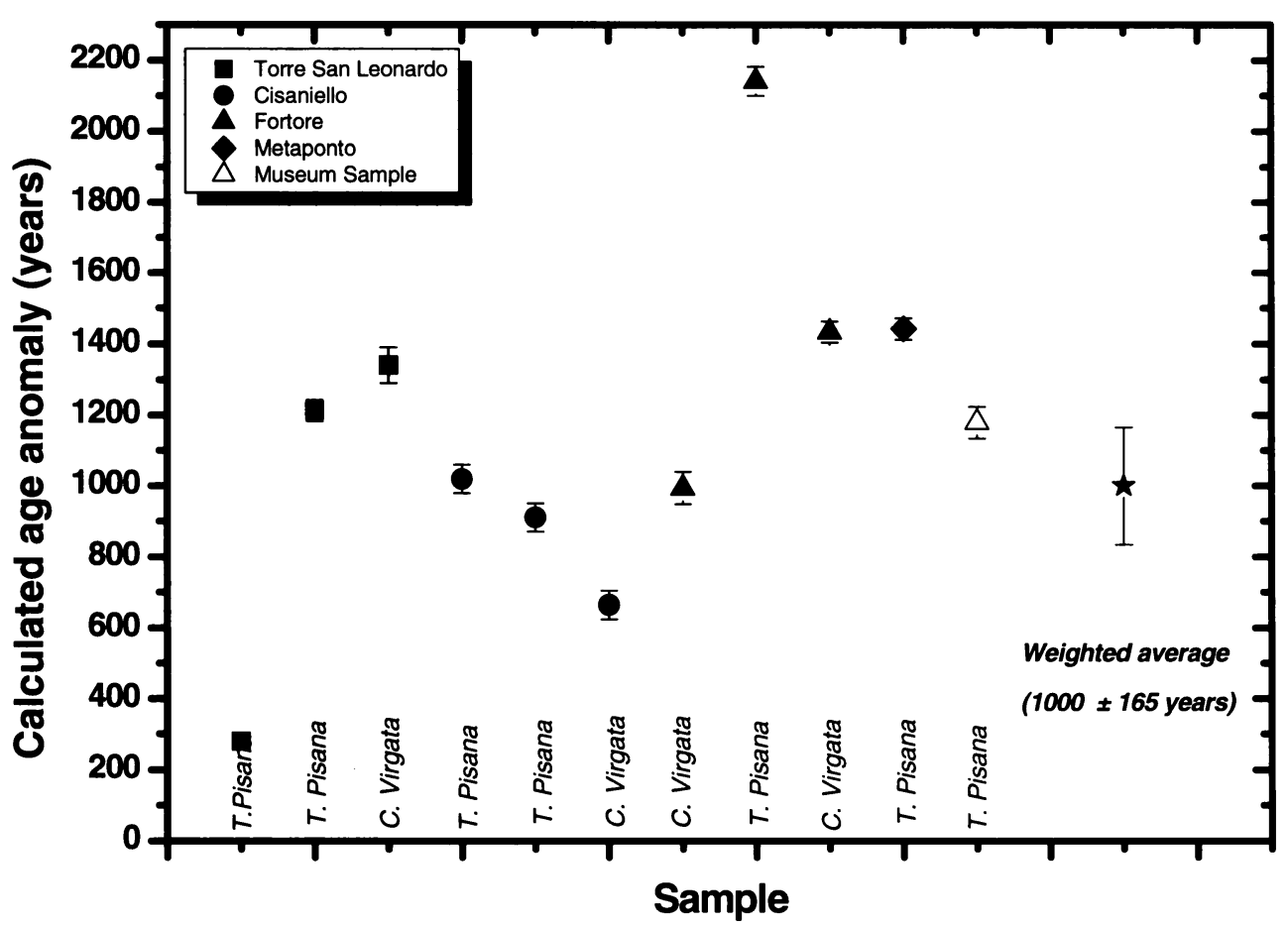

Figure 4 Measured ${ }^{14} \mathrm{C}$ age anomaly for the samples collected alive in 2004 and for the AD 1850 museum sample

An estimation of the proportion of the different carbon sources in the diet is given in a ternary plot (Figure 5). The measurements show that all the samples are clustered in an area with a proportion of limestone-derived carbon in the gastropod shells ranging from 3 to $23 \%$, a plant-derived proportion higher than $50 \%$, and an air-derived proportion below $50 \%$.

For the museum sample, a ${ }^{14} \mathrm{C}$ concentration of $86.11 \pm 0.60 \mathrm{pMC}$ and a $\delta^{13} \mathrm{C}$ value of $-9.6 \pm 0.1 \%$ o were measured, corresponding to an age anomaly of $1100 \pm 45 \mathrm{yr}$ (Figure 4) and a limestone-derived portion in the diet of $13 \%$ (Figure 5). It is interesting to note that the weighted average age anomaly calculated from the scattering of the live-collected samples data is $1000 \pm 180 \mathrm{yr}$, which is in agreement, within $1 \sigma$, with the value measured for the museum sample $(1100 \pm 45 \mathrm{BP})$.

A comparison of the age anomaly measured for the 2 species of collected gastropods (Theba pisana and Cernuella virgata) does not show any significant difference between the 2 set of samples. In fact, the average age anomaly measured for the $T$. pisana samples $(n=7)$ is $950 \pm 235 \mathrm{BP}$, which is comparable (relative difference $0.5 \sigma$ ) with the average value measured for the $C$. virgata samples $(n=4), 1150 \pm 160 \mathrm{BP}$.

Three kind of samples, both terrestrial and marine, were collected from the erosive layer of the sedimentary dune ridge sequence at Il Pilone: 4 cuttlebone samples, charcoal, and terrestrial gastropods. Results of the ${ }^{14} \mathrm{C}$ AMS analysis are summarized in Figure 6. The measurements show consistent 


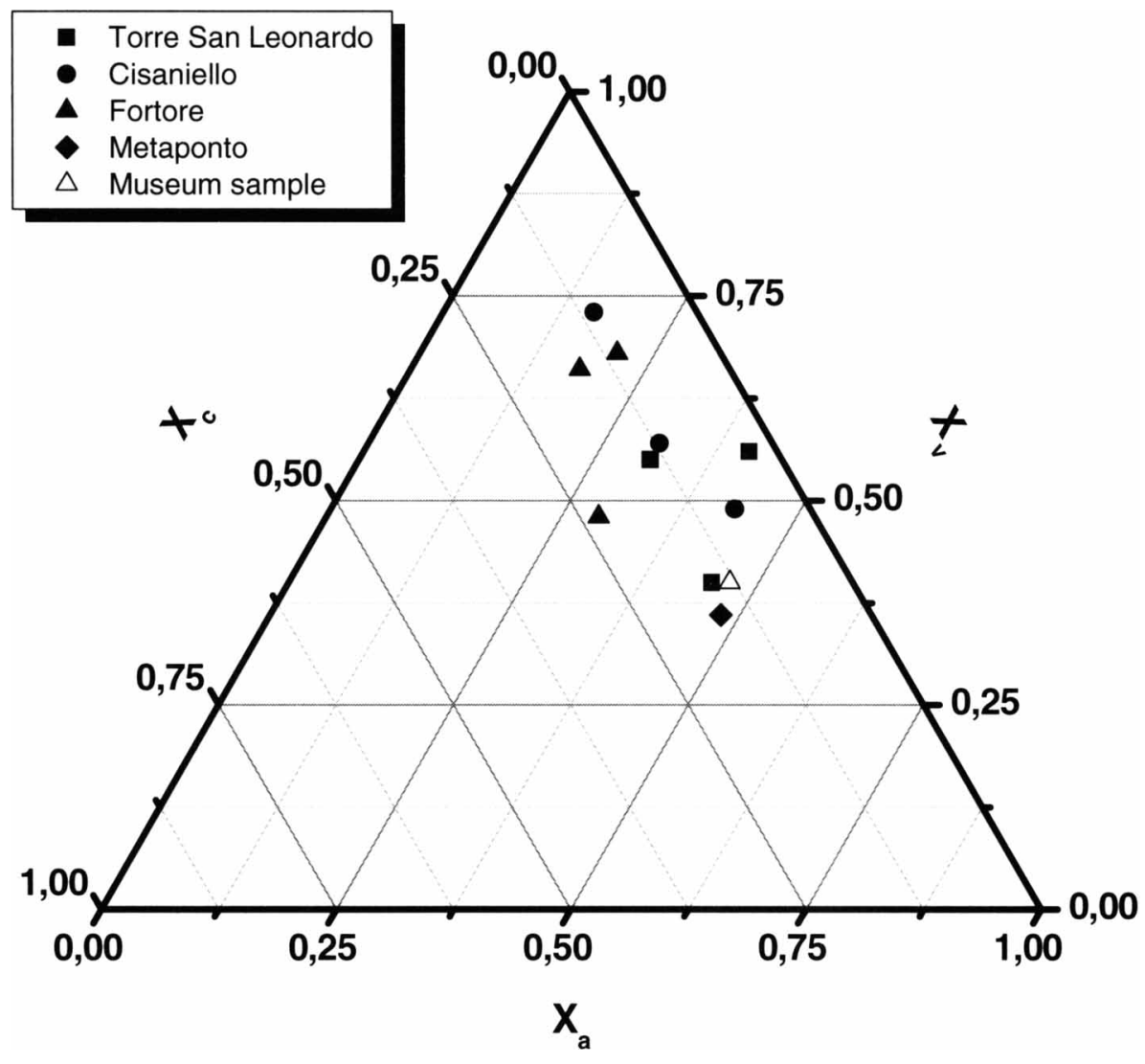

Figure 5 Ternary plot of the air- $\left(\mathrm{X}_{\mathrm{a}}\right)$, plant- $\left(\mathrm{X}_{\mathrm{v}}\right)$, and limestone $\left(\mathrm{X}_{\mathrm{c}}\right)$-derived proportions in the gastropods' diet.

results between the charcoal and the cuttlebone samples if a marine reservoir age of $R_{\text {marine }} \sim 340 \mathrm{yr}$ is taken into account; while both the gastropods samples gave, again, ${ }^{14} \mathrm{C}$ ages that were too old and inconsistent with their stratigraphic position in the layer. For these samples, the age anomaly $(\Delta)$ calculated as difference between the age of the gastropod samples and the age of the charcoal-can be estimated as 2084 and $2183{ }^{14} \mathrm{C}$ yr, with an average value of $2140 \pm 40 \mathrm{yr}$, corresponding to a limestone-derived proportion in the gastropods' diet of 22.5 and $23.4 \%$, respectively, significantly higher than the value measured for the modern and the museum samples. For these samples, however, the estimation of the age anomaly is completely based on the assumption that the charcoal samples and the fossil shells are contemporary; and this introduces, evidently, an uncertainty in the age anomaly calculation that was not present for both the modern and the museum samples.

The next step would be, of course, to try to correct the ${ }^{14} \mathrm{C}$ ages of these kinds of organisms for the measured age anomaly. A first-order approach could be to simply subtract from the measured ${ }^{14} \mathrm{C}$ ages the average anomaly as suggested by Goodfriend and Ellis (2000). In this case, the $\sigma_{\text {tot }}$ error associated to the "anomaly-corrected" age can be estimated by combining the uncertainties associated with the ${ }^{14} \mathrm{C}$ age of the sample $\left(\sigma_{s}\right)$ and with the estimation of the age anomaly $\left(\sigma_{\text {anom }}\right)$ as:

$$
\sigma_{t o t}=\sqrt{\sigma_{s}^{2}+\sigma_{\text {anom }}^{2}}
$$




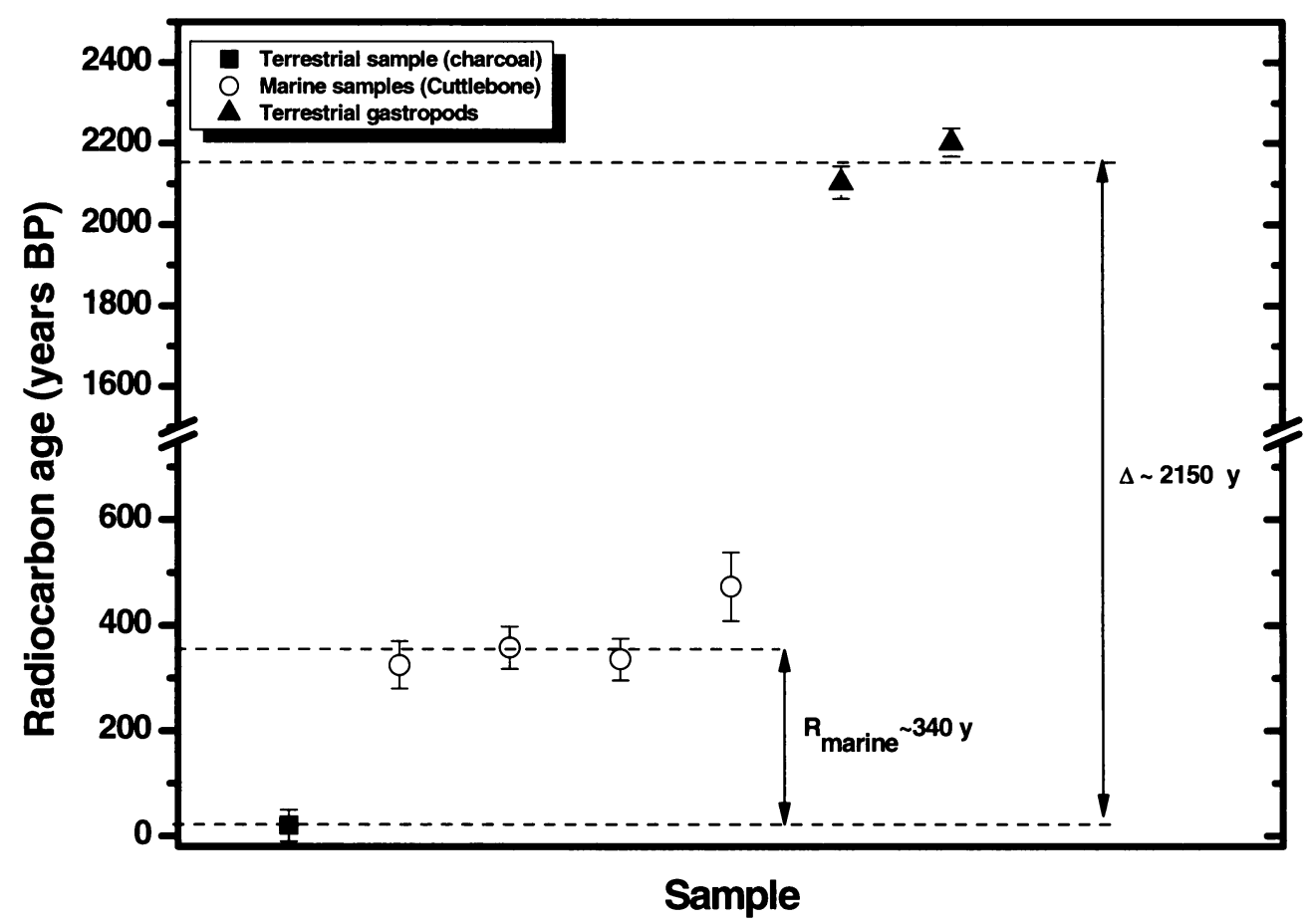

Figure 6 Results of the isotopic analysis carried out on the marine and terrestrial samples found in the same layer of the Il Pilone sedimentary sequence.

Although this approach can give reasonable results in some applications, it is, however, unsatisfactory for those samples (i.e. relatively young samples) where $\sigma_{s}$ is significantly smaller than $\sigma_{\text {anom }}$ and for those applications (particularly in archaeology) where higher chronological precision is needed. Furthermore, our results seem to show that the measured age anomalies are quite scattered even for samples collected in similar geological and environmental settings, and the application of this "straightforward" subtraction method could be troublesome in many cases.

The other possibility would be to use the model for the carbon uptake and the stable isotope results, expressed through the $\delta^{13} \mathrm{C}$ term, to correct the data. Figure 7 shows the relationship between the estimated age anomaly and the measured $\delta^{13} \mathrm{C}$ term. Although a relationship can be claimed, it is quite weak $(R \sim 0.3)$, indicating that the limestone does not have only a direct effect on $\delta^{13} \mathrm{C}$, as assumed by the model, and that this approach cannot be used for age-correction purposes (Tamers 1970; Evin et al. 1980; Goodfriend and Hood 1983).

\section{CONCLUSIONS}

We investigated the possible presence of an anomaly in the ${ }^{14} \mathrm{C}$ age measured on the shells of 2 species of terrestrial gastropods (Theba pisana and Cernuella virgata) diffused in coastal areas of Apulia, southern Italy. Both modern animals were sampled live in defined geological and environmental settings and pre-bomb fossil samples were analyzed. We found that all the measured samples exhibit anomalously old ${ }^{14} \mathrm{C}$ ages and no statistically significant difference was measured between the 2 studied species. 


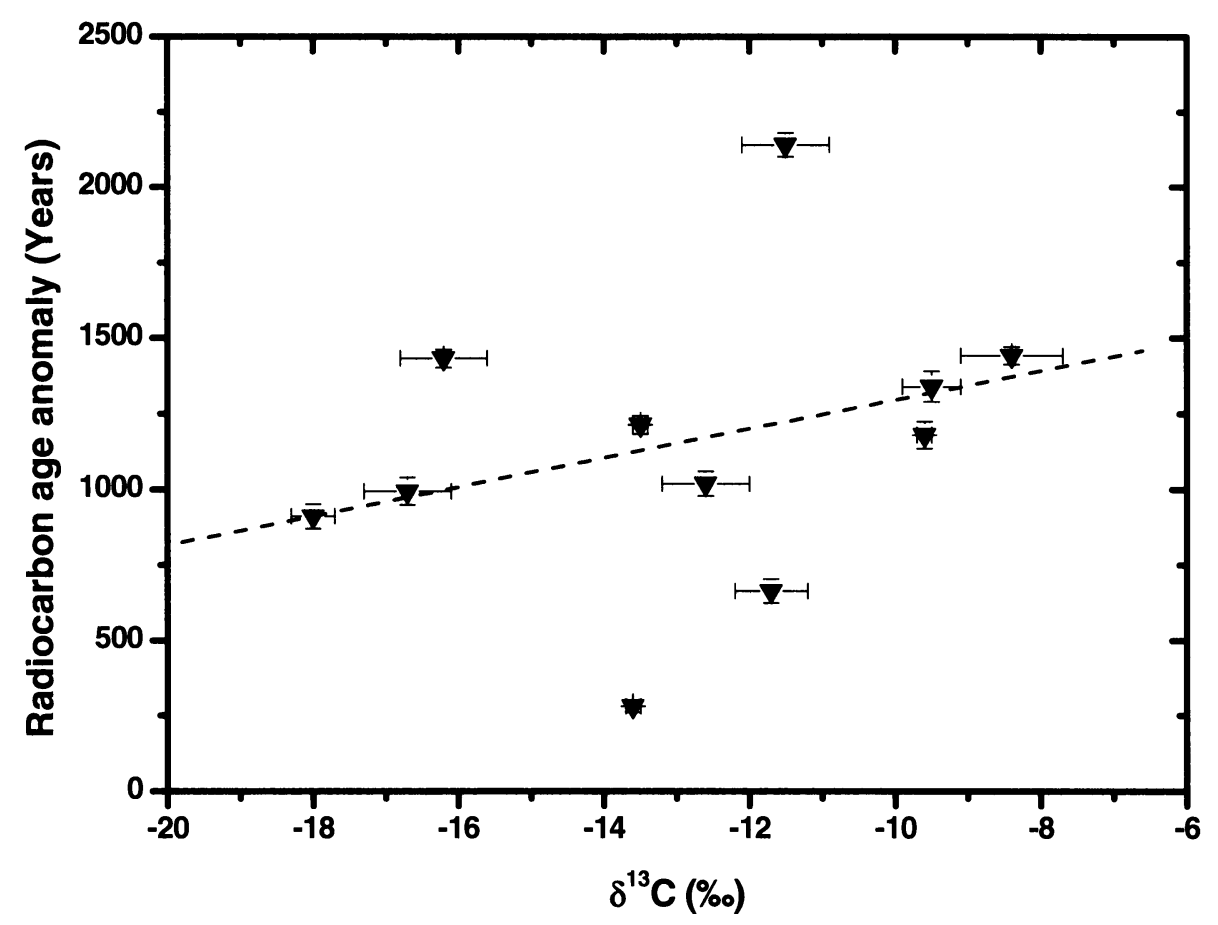

Figure 7 Relationship between the age anomaly and the measured $\delta^{13} \mathrm{C}$ value

We confirm the conclusions of other authors that a source of ${ }^{14} \mathrm{C}$-depleted carbon is present in the diet of these organisms and that this is probably calcium carbonate derived from limestone. Our measurements indicate that the magnitude of the age anomaly for the studied species sampled along the Mediterranean coasts of the Apulia region, southern Italy, is as high as 1000 yr.

\section{ACKNOWLEDGMENTS}

We wish to thank Prof F Giusti (Department of Environmental Science, University of Siena) for helpful discussions and for supplying the Theba pisana pre-bomb sample. This work was supported by the Italian Ministry for Research (MIUR) through the projects SIDART (Sistema Integrato di Diagnostica dei Beni Artistici) and Piano Coordinato Catania-Lecce, co-funded by the European Union. This work was financially supported by the Graduate School of Geomorphology and Environmental Dynamics of University of Bari, by Project Ateneo 2004: "Valutazione dell'effetto aging sui depositi costieri dell'Italia Meridionale" (Project leader: G Mastronuzzi) and by National Project COFIN MIUR "Effetti morfologici di onde catastrofiche sulle coste dell'Italia meridionale" (Morphological effects of catastrophic waves on the coasts of southern Italy) (Project leader: G Mastronuzzi), part of "Valutazione del Rischio da tsunami in Arco Calabro ed in Adriatico" (Assessment of tsunami risk on Calabrian Arc and on Adriatic Sea) (Project leader: Prof Stefano Tinti, Università degli Studi di Bologna).

This is an Italian contribution to the IGCP Project \#495, International Geological Correlation Program "Quaternary Land-Ocean Interactions: Driving Mechanisms and Coastal Responses" of UNESCO-IUGS (Project leader: Dr Anthony Long, University of Durham; and Dr Shahidul Islam, University of Chittangong, Bangladesh). 


\section{REFERENCES}

Calcagnile L, Quarta G, D'Elia M, Rizzo A, Gottdang A, Klein M, Mous DJW. 2004. A new accelerator mass spectrometry facility in Lecce, Italy. Nuclear Instruments and Methods in Physics Research B 223-224: 16-20.

Calcagnile L, Quarta G, D'Elia M. 2005. High-resolution accelerator-based mass spectrometry: precision accuracy and background. Applied Radiation and Isotopes 62(4):623-9.

Caldara M, Centenaro E, Mastronuzzi G, Sansò P, Sergio A. 1998. Features and present evolution of Apulian coast (southern Italy). Journal of Coastal Research, Special Issue 26:55-64.

Cowie RH. 1984. The life-cycle and productivity of the land snail Theba pisana (Mollusca: Helicidae). Journal of Animal Ecology 53(1):311-25.

D’Elia M, Calcagnile L, Quarta G, Sanapo C, Laudisa M, Toma U, Rizzo A. 2004. Sample preparation and blank values at the AMS radiocarbon facility of the University of Lecce. Nuclear Instruments and Methods in Physics Research B 223-224:278-83.

Evin J, Marechal J, Pachiaudi C, Puissegur JJ. 1980. Conditions involved in dating terrestrial shells. Radiocarbon 22(2):545-55.

Giusti F, Castagnolo L. 1982. I molluschi terrestri delle dune italiane: brevi cenni di ecologia, elenco delle specie e chiavi per il loro riconoscimento. In: Quaderni sulla "Struttura delle Zoocenosi Terrestri," 3. Ambienti mediterranei, 1. Le coste sabbiose. Rome: CNR. p 51-102. In Italian.

Goodfriend GA. 1987. Radiocarbon age anomalies in shell carbonate of land snails from semi-arid areas. Radiocarbon 29(2):159-67.

Goodfriend GA. 1992. The use of land snails shells in paleoenvironmental reconstruction. Quaternary Science Reviews 11(6):665-85.

Goodfriend GA, Ellis GL. 2000. Stable carbon isotope record of middle to late Holocene climate changes from land snail shells at Hinds Cave, Texas. Quaternary International 67(1):47-60.

Goodfriend GA, Ellis GL. 2002. Stable carbon and oxygen isotopic variations in modern Rabdotus land snail shells in the southern Great Plains, USA, and their relation to environment. Geochimica et Cosmochimica Acta 66(11):1987-2002.

Goodfriend GA, Hood DG. 1983. Carbon isotope analysis of land snail shells: implications for carbon sources and radiocarbon dating. Radiocarbon 25(3):810-30.

Goodfriend GA, Margaritz M. 1987. Carbon and oxygen isotope composition of shell carbonate of desert land snails. Earth and Planetary Science Letters 86(2-4): 377-88.

Goodfriend GA, Stipp JJ. 1983. Limestone and the problem of radiocarbon dating of land-snail shell carbonate. Geology 11(10):575-7.

Goodfriend GA, Ellis GL, Toolin LJ. 1999. Radiocarbon age anomalies in land snail shells from Texas: ontogenetic, individual and geographic patterns of variation. Radiocarbon 41(2): 149-56.

Jedoui Y, Kallel N, Fontugne M, Ismail HB, M'Rabet A, Montacer M. 1998. A high relative sea-level stand in the middle Holocene of southeastern Tunisia. Marine Geology 147(1-4):123-30.

Mastronuzzi G, Romaniello L. Forthcoming. Holocene aeolian morphogenetic phases in southern Italy: problems in ${ }^{14} \mathrm{C}$ age determinations using terrestrial gastropods. Quaternary International.

Mastronuzzi G, Sansò P. 2002. Holocene coastal dune development and environmental changes in Apulia (southern Italy). Sedimentary Geology 150(1-2):13952.

Pigati JS. 2002. On correcting ${ }^{14} \mathrm{C}$ ages of gastropod shell carbonate for fractionation. Radiocarbon 44(3):75560.

Quarta G, D'Elia M, Rizzo GA, Calcagnile L. 2005. Radiocarbon dilution effects induced by industrial settlements in southern Italy. Nuclear Instruments and Methods in Physics Research B 240(1-2):458-62.

Romaniello L, Quarta G, Mastronuzzi G, D'Elia M, Calcagnile L. $2007 .{ }^{14} \mathrm{C}$ age anomalies in modern land snails shell carbonate from southern Italy. Quaternary Geochronology. doi: 10.1016/j.quageo.2007.01.006.

Rubin M, Likins RC, Berry EG. 1963. On the validity of radiocarbon dates from snail shells. Journal of Geology 71(1):84-9.

Sacchi CF. 1990. Observations sur le cycle biotique de Theba pisana (Müller) (Gastropoda, Polmonata) en Europe et en Australie. Bollettino Malacologico 26(58):73-82. In French.

Stott LD. 2002. The influence of diet of the $\delta^{13} \mathrm{C}$ of shell carbon in the pulmonate snail Helix aspersa. Earth and Planetary Letters 195(3-4):249-59.

Tamers MA. 1970. Validity of radiocarbon dates on terrestrial snail shells. American Antiquity 35(1):94-100.

Yates T. 1986. Studies of non-marine mollusks for the selection of shell samples for radiocarbon dating. Radiocarbon 28(2A):457-63.

Zhou W, Head MJ, Wang F, Donahue DJ, Jull AJT. 1999. The reliability of AMS radiocarbon dating of shells from China. Radiocarbon 41(1): 17-24. 